\title{
Analisis Budaya Organisasi Pada Coffeeshop Atlas n Co Menggunakan Organizational Culture Assesment Instrument (OCAI)
}

\author{
Adetama Hadi Putra ${ }^{1}$; Rudi Elyadi ${ }^{2}$ \\ FEB Unika Soegijapranata \\ email: adetamaputra16@gmail.com¹ ; rudi@unika.ac.id ${ }^{2}$
}

\begin{abstract}
Coffee shop is recently becoming a trend among the people, especially in metropolitan cities such as Semarang. The increasing number of coffee shops makes business competition more stringent. Organizational culture becomes one of the important roles in human resource management strategies and making a coffee shop has strong characteristics in the effort of winning the competition. This research aims to look at the currently perceived organizational culture and expected organizational culture in the coffee shop. In the process of measurement and analysis, the researcher uses a research instrument, which is the Organizational Culture Assessment Instrument (OCAI). The researcher specifically chooses a coffee shop as the subject of this research, which is Atlas $n$ Co. The subjects in this research are 15 people who are the employees of Atlas $n$ Co. The result of this research indicates that the currently perceived organizational culture and the expected organizational culture have the same result, which is the Clan culture. This research provides recommendations for Atlas $n$ Co in their effort to maintain the recently owned organizational culture in order to be able to compete with other coffee shops.
\end{abstract}

\section{Keyword: coffee shop, organizational culture, OCAI}

\begin{abstract}
Abstrak
Coffeeshop saat ini menjadi trend di kalangan masyarakat khususnya di kota metropolitan seperti kota Semarang. Semakin banyaknya coffeeshop membuat persaingan bisnis menjadi semakin ketat. Budaya organisasi menjadi salah satu peran penting dalam strategi manajemen sumber daya manusia dan membuat sebuah coffeeshop memiliki ciri khas yang kuat dalam upaya memenangkan persaingan tersebut. Penelitian ini bertujuan untuk melihat budaya organisasi yang dirasakan saat ini dan budaya organisasi yang diharapkan pada coffee shop. Dalam proses pengukuran dan analisisnya, peneliti menggunakan instrumen penelitian yaitu Organizational Culture Assesment Instrument (OCAI). Peneliti secara khusus memilih sebuah coffeeshop untuk subjek penelitian ini yaitu coffeeshop Atlas n Co. Subjek penelitian dalam penelitian ini berjumlah 15 orang yang merupakan karyawan Atlas n Co. Hasil penelitian ini menunjukan bahwa budaya organisasi yang saat ini dirasakan dengan budaya organisasi yang diharapkan memiliki hasil yang sama yaitu budaya Clan. Penelitian ini memberikan rekomendasi kepada Atlas n Co dalam upaya mempertahankan budaya organisasi yang saat ini sudah dimiliki agar mampu bersaing dengan coffeeshop lain.
\end{abstract}

Kata kunci: coffee shop, budaya organisasi, OCAI 


\section{PENDAHULUAN}

Kebiasaan minum kopi bagi masyarakat Indonesia sudah ada sejak zaman dahulu kala. Menurut data dari International Coffee Organization (ICO) tahun 2016 Indonesia yang juga merupakan salah satu negara penghasil biji kopi terbaik dunia juga menjadi salah satu faktor pendukungnya (Humaniora, 2018).. Maka dari itu jumlah penikmat kopi di Indonesia juga terus meningkat jumlahnya. Menurut data dari ICO pertumbuhan penikmat kopi di Indonesia mencapai $8 \%$, melebihi pertumbuhan pecinta kopi dunia yang hanya 6\% (Humaniora, 2018).

Menurut Sahro, Manajer Marketing Coffee Bean \& Tea Leaf, saat ini terdapat pergeseran trend di masyarakat yang semula biasa minum kopi di hotel berbintang beralih ke coffeeshop(Herlyana, 2012) . Atlas n Co sebagai salah satu coffeeshop yang memiliki tingkat persaingan yang tinggi membuat Atlas $n$ Co juga harus mengenali budayanya sendiri agar dapat melakukan upaya upaya untuk memperkuat karakteristik budayanya guna bertahan dalam persaingan yang semakin ketat. Fungsifungsi budaya organisasi jika dapat terealisasikan dengan baik juga akan menimbulkan dampak positif bagi perusahaan yaitu karakteristik yang unik dan kuat yang membuat perusahaan mempunyai ciri khas tersendiri yang juga secara tidak langsung akan berpengaruh ke konsumen. Dalam mengan alisis budaya organisasi yang saat ini terjadi dan yang diharapkan oleh Atlas n Co, dengan menggunakan instrumen Organizational Culture Instrument (OCAI).

\section{RUMUSAN MASALAH}

Bagaimanakah profil budaya organisasi coffee shop Atlas n Co saat ini dan yang diharapkan dimasa yang akan datang, berdasarkan persepsi karyawan?

\section{TUJUAN PENELITIAN MANFAAT PENELITIAN}

DAN

Tujuan: Untuk mengetahui profil budaya organisasi pada coffeeshop Atlas $\mathrm{n}$ Co saat ini dan yang diharapkan dimasa yang akan datang.

Manfaat: Dapat dijadikan bahan referensi untuk memahami budaya organisasinya dan diharapkan dapat memberikan informasi mengenai budaya apa yang saat ini sedang berjalan dan diharapkan dimasa mendatang. bagi coffeeshop Atlas n Co

\section{LANDASAN TEORITIS}

\section{Pengertian Budaya Organisasi}

Budaya organisasi dapat didefinisikan sebagai perangkat sistem nilai - nilai (values), keyakinan-keyakinan (beliefs), asumsi-asumsi (assumptions), atau norma-norma yang telah lama berlaku, disepakati dan diikuti oleh para anggota suatu organisasi sebagai pedoman perilaku dan pemecahan masalah-masalah organisasinya (Sutrisno, Budaya Organisasi, 2010).

Budaya organisasi yang kuat mendukung tujuan-tujuan perusahaan, sebaliknya yang lemah atau negatif menghambat atau bertentangan dengan tujuan-tujuan perusahaan(Sutrisno, Budaya Organisasi, 2010). Perusahaan yang efektif ialah perusahaan yang membudayakan nilai-nilai primer yang diperlukan untuk kepentingan operasi perusahaan, yaitu asas-asas tujuan, konsesus, keunggulan, prestasi, empiri, kesatuan, keakraban, dan integritas menurut Miller dalam Sutrisno ( 2010). yang berarti semakin kuat budaya sebuah perusahaan akan semakin efektif perusahaan tersebut dan semakin kompetitif. 
Jurnal PRAXIS | Vol. 3 | No. 1 | September 2020

Organizational Culture Assesment Instrument (OCAI)

OCAI merupakan sebuah instrument yang membagi budaya organisasi menjadi 4 jenis yaitu clan culture, adhocracy cukture, market culture, dan hierarchy culture. Dalam 4 jenis budaya organisasi tersebut terdapat 6 indikator yang mewakili masing - masing jenis budaya organisasi yang didalamnya terbagi menjadi 24 pertanyaan. Dalam penerapannya metode Organizational Culture Assesment Instrument (OCAI) memiliki keunggulan yaitu melihat tipetipe budaya yang ada sebagai sesuatu yang tidak terpisahkan, hal itu didasarkan pada kenyataan bahwa setiap organisasi merupakan campuran dari keempat tipe yang ada. Dalam metode ini juga dapat terlihat budaya organisasi yang dirasakan saat ini dan yang dihaarapkan. Sehingga metode ini dapat menunjukkan ke arah mana organisasi dikelompokkan berdasarkan budayanya dan apakah budaya organisasi sekarang telah mendukung misi dan tujuan perusahaan. OCAI juga berguna untuk mengidentifikasi elemen-elemen di dalam budaya yang dapat melawan misi dan tujuan tersebut, agar perbaikanperbaikan dari masih-masing elemen yang ada dapat dilakukan(Opi, 2015). Untuk kelemahannya sendiri OCAI memiliki kelemahan dalam proses pengisian kuisioner yang berupa angka atau skor dimana metode ini cukup memberatkan responden untuk membagi dan menghitung skor yang harus memiliki total skor 100 pada tiap indikatornya.

\section{Jenis Budaya Organisasi (OCAI)}

Pada dasarnya, keunikan-keunikan organisasi merupakan kombinasi dari empat jenis atau tipe budaya organisasi utama yaitu Clan Culture (Kebudayaan Klan), Hierarchy culture (Kebudayaan Hirarki), Market culture (Kebudayaan Pasar) dan Adhocracy culture
(Kebudayaan Adhokrasi) (Cameron \& Quinn, 2006, 2011).

\section{Kebudayaan Klan (Clan Culture)}

Dalam organisasi yang berkebudayaan klan ini, setiap anggota dalam organisasi memiliki rasa kebersamaan dan kekeluargaan. Para pemimpin atau pemimpin organisasi dianggap sebagai mentor dan bahkan sebagai figur seorang ayah yang bertindak sebagai kepala keluarga.

\section{Kebudayaan Adhokrasi (Adhocracy Culture)}

Budaya organisasi jenis ini didasarkan pada energi dan kreativitas. Anggota organisasi atau Karyawan didorong untuk berani mengambil risiko, berekspreimen dan berpikir di luar kebiasaan untuk menyelesaikan sesuatu. Para pemimpin organisasi dianggap sebagai inovator dan pengusaha (entrepreneur)..

\section{Kebudayaan Pasar (Market Culture)}

Budaya ini dibangun atas dasar dinamika persaingan dan pencapaian hasil nyata, fokusnya adalah pada tujuan atau hasil. Organisasi Tipe Kebudayaan Pasar ini berpusat pada lingkungan eksternal yaitu pelanggannya. Mereka lebih mendahulukan kepentingan pelanggan atau pangsa pasar dan laba perusahaan dibandingkan dengan kepuasan karyawannya maupun pengembangan sumber daya manusianya.

\section{Kebudayaan Hirarki (Hierarchy culture)}

Budaya Organisasi jenis Kebudayaan Hirarki ini dilandasi oleh struktur dan kendali. Lingkungan kerja bersifat formal dan pengendalian yang ketat. Kepemimpinan didasarkan pada koordinasi dan pemantauan yang 
Jurnal PRAXIS | Vol. 3 | No. 1 | September 2020

terorganisir dengan budaya yang menekankan efisiensi dan prediktabilitas. Nilai dari kebudayaan hirarki ini adalah konsistensi dan keseragaman. Sukses dalam konteks organisasi yang mengadopsi kebudayaan hirarki ini adalah perencanaan (planning) yang andal, kualitas produk dan layanan yang tinggi, pengiriman yang tepat waktu dan biaya operasional yang rendah. Manajemen harus memastikan kepastian pekerjaan dan prediktabilitas.

\section{Indikator Budaya Organisasi (OCAI)}

Untuk melakukan identifikasi pada budaya organisasi sebuah perusahaan, instrumen yang dapat digunakan ada OCAI (Organizational Culture Assessment Instrument). terdapat enam indikator budaya organisasi (OCAI online, 2010), yaitu:

\section{Karakter Dominan}

Indikator ini menunjukan kondisi / situasi lingkungan organisasi, apa yang dirasakan oleh anggota organisasi saat mereka berada didalam organisasi tersebut. Dengan perhitungan sistematis pada instrument OCAI akan menghasilkan gambaran budaya apa yang dominan pada lingkungan suatu organisasi.

\section{Kepemimpinan Organisasi}

Indikator ini menunjukan model kepemimpinan yang dirasakan di dalam suatu organisasi dan persepsi para anggota organisasi tentang kepemimpinan. Dengan perhitungan sistematis instrumen OCAI pada indikator ini akan terlihat budaya apa yang menjadi dasar dari kepemimpinan organisasi tersebut

3. Pengelolaan Karyawan

Indikator ini menunjukan bagaimana cara pengelolaan anggota di dalam sebuah organisasi. Dengan perhitungan sistematis instrumen OCAI pada indikator ini akan terlihat budaya apa yang mendasari pengelolaan anggota organisasi.

\section{Perekat Organisasi}

Indikator ini menunjukan faktor yang mendorong anggota organisasi berada di dalam organisasi. Dengan perhitungan sistematis instrumen OCAI, budaya yang menjadi faktor perekat anggota organisasi akan dapat dilihat dengan baik.

\section{Penekanan Strategis}

Indikator ini menunjukan bagaimana organisasi menitikberatkan strategi yang dijalankan dalam mencapai sebuah tujuan. Dengan perhitungan sistematis instrumen OCAI pada indikator ini akan terlihat budaya yang dominan pada penekanan strategi sebuah organisasi.

\section{Kriteria Keberhasilan}

Indikator ini menunjukan hal apa saja yang menjadi kriteria keberhasilan di dalam sebuah organisasi. Dengan perhitungan sistematis instrumen OCAI pada dimensi ini akan terlihat budaya yang dominan dan mendasari kriteria keberhasilan sebuah organisasi. 


\section{KERANGKA PIKIR PENELITIAN}

Penelitian ini akan dianalisis dengan menggunakan kerangka berpikir yang dibentuk dari organizational culture assessment instrument (OCAI) (OCAI online, 2010).

Persepsi karyawan terhadap budaya organisasi pada coffeeshop Atlas n Co

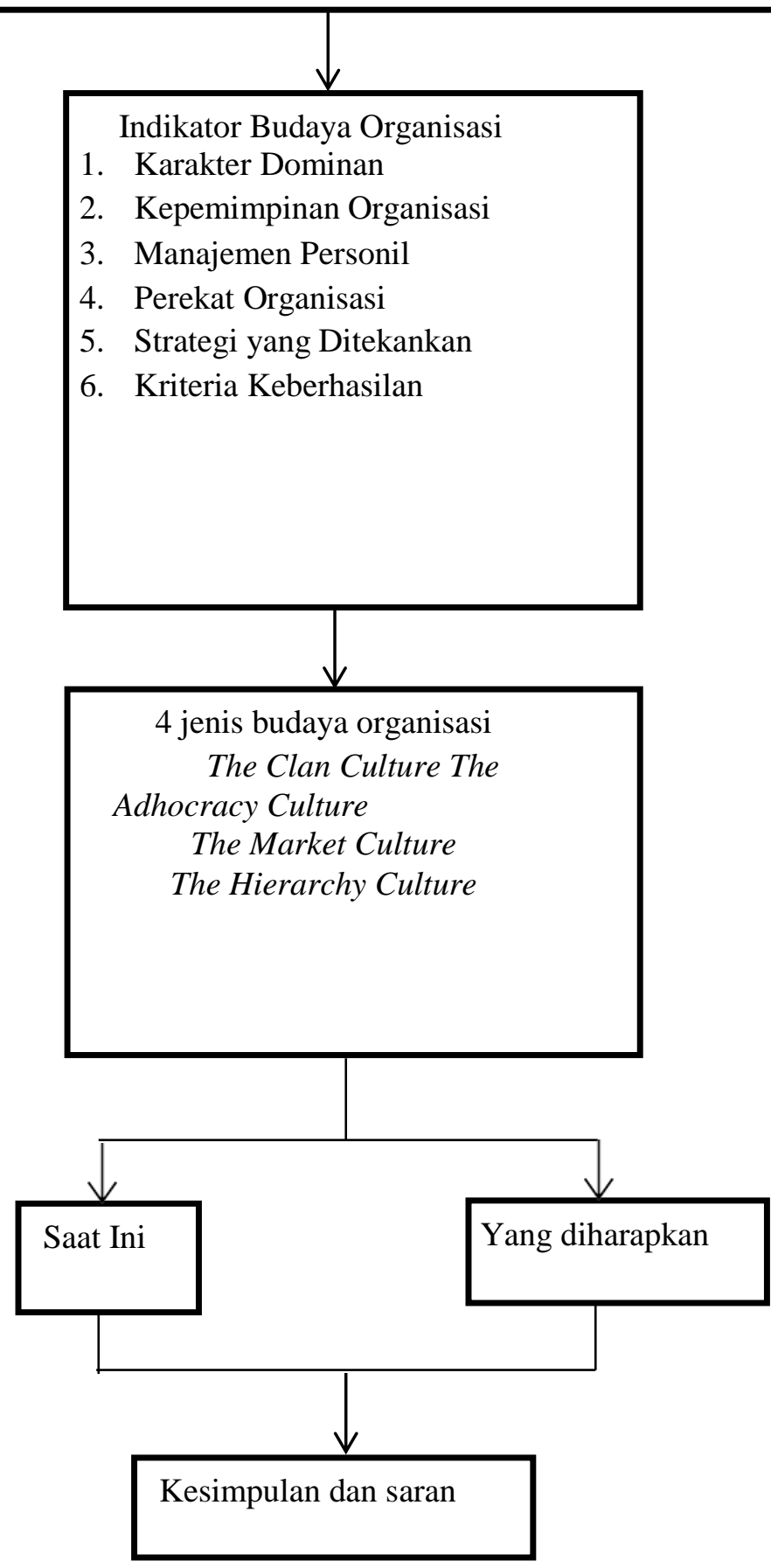

Gambar 1 Kerangka Pikir Penelitian 


\section{METODE PENELITIAN}

\section{Obyek dan Lokasi Penelitian}

Obyek dari penelitian ini adalah Karyawan Atlas n Co meliputi barista, koki, administrasi, community manager, beserta manajer. Lokasi coffeeshop Atlas n Co yang berlokasi di Jl. Jati raya no 51 Banyumanik, Semarang.

\section{Populasi}

Populasi adalah selurah karyawan Atlas n Co , terdiri dari : yang terdiri dari 7 barista, 5 koki, 1 administrasi, 1 event organizer dan 1 Manajer. Karena jumlahnya relatif kecil, maka seluruh populasi dijadikan respo (15 Responden)

\section{Jenis dan Sumber Data}

Jenis data yang digunakan dalam penelitian ini adalah data primer dan sumber data darui karyawan Atlas n Co yang berperan sebagai responden.

\section{Teknik Pengumpulan Data}

Teknik pengumpulan data dalam peneltian ini menggunakan kuisioner, sesuai dengan konsep OCAI.

\section{Analisis Data}

Analisis Deskriptif ,yaitu mengambarkan hasil dari data yang telah terkumpul dengan menggunakan instrumen OCAI (Organizational Culture Assessment Instrument). OCAI merupakan salah satu instrumen yang dapat digunakan untuk mengidentifikasi budaya pada suatu organisasi.

Langkah mengolah dan menganalisis data menggunakan OCAI sebagai berikut :

1. Tiap indikator dibagi menjadi 4 poin (A,B,C,D).
2. Responden diminta untuk memberikan skor pada tiap poin indikator berdasarkan dengan kondisi budaya yang dirasakan saat ini dan yang diharapkan.

3. Skor tertinggi diberikan pada alternatif yang paling sesuai dengan kondisi Atlas $\mathrm{n}$ Co berdasarkan persepsi responden.

4. Skor akan diintepretasikan ke dalam sebuah chart dengan tipe radar sehingga dapat terlihat dengan jelas kecenderungan budaya yang terjadi saat ini dan budaya yang diharapkan.

5. Budaya yang terjadi saat ini akan terlihat melalui garis berwarna biru, sementara budaya yang diharapkan ditandai oleh garis berwarna merah muda.

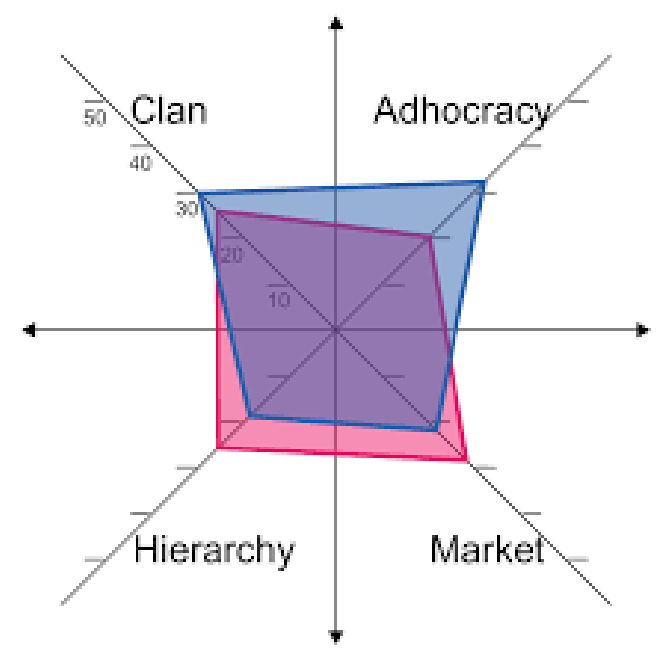

Gambar 2 .Organizational Culture Assesment Instrument (OCAI)

Sumber : (OCAI online, 2010)

\section{Menarik Kesimpulan}

Kesimpulan yang utuh berdasarkan Organization Culture Assesment Instrument dengan empat jenis budaya 
Jurnal PRAXIS | Vol. 3 | No. 1 | September 2020

organisasi yaitu : Kultur Klan (Clan Culture), Kultur Adhokrasi (Adhocracy Culture), Kultur Market (Market culture) dan Kultur Hierarki (Hierarchy Culture)

\section{ANALISIS DAN PEMBAHASAN}

Setelah mengetahui profil budaya saat ini maupun yang diharapankan pada setiap dimensi budaya, maka dapat diperoleh adanya keragaman profilbudaya organisasi pada karyawan coffee shop Atlas n Co. Keragaman tersebut dapat dilihat pada grafik berikut ini

\section{a. Perbandingan profil budaya organisasi dimensi karakter dominan pada saat ini dan yang diharapkan karyawan Atlas n Co}

Berdasarkan gambar 3, dibawah ini dapat diketahui bahwa skor pada clan culture saat ini mendapatkan skor tertinggi yaitu 32 yang ditunjukkan dengan garis berwarna biru yang menunjukkan bahwa saat ini karyawan Atlas n Co merasakan budaya clan yang sangat kuat pada dimensi karakter dominan. Lalu pada harapannya juga karyawan Atlas n Co mengharapkan budaya clan tetap menjadi karakteristik dominan di coffee shopAtlas n Co yang juga dapat dilihat pada gambar diatas dimana clan culture juga mendapatkan skor tertinggi yaitu 30 yang ditunjukkan dengan garis berwarna merah. Berdasarkan hasil tersebut dapat disimpulkan bahwa karyawan Atlas n Co merasakan sekaligus menginginkan Atlas n Co sebagai tempat pribadi seperti rumah dan keluarga besar dengan karakter orang - orangnya yang saling berbagi satu sama lain.

Berikut adalah grafik budaya organisasi pada dimensi karakter dominan pada saat ini dan yang diharapkan karyawan Atlas n Co :

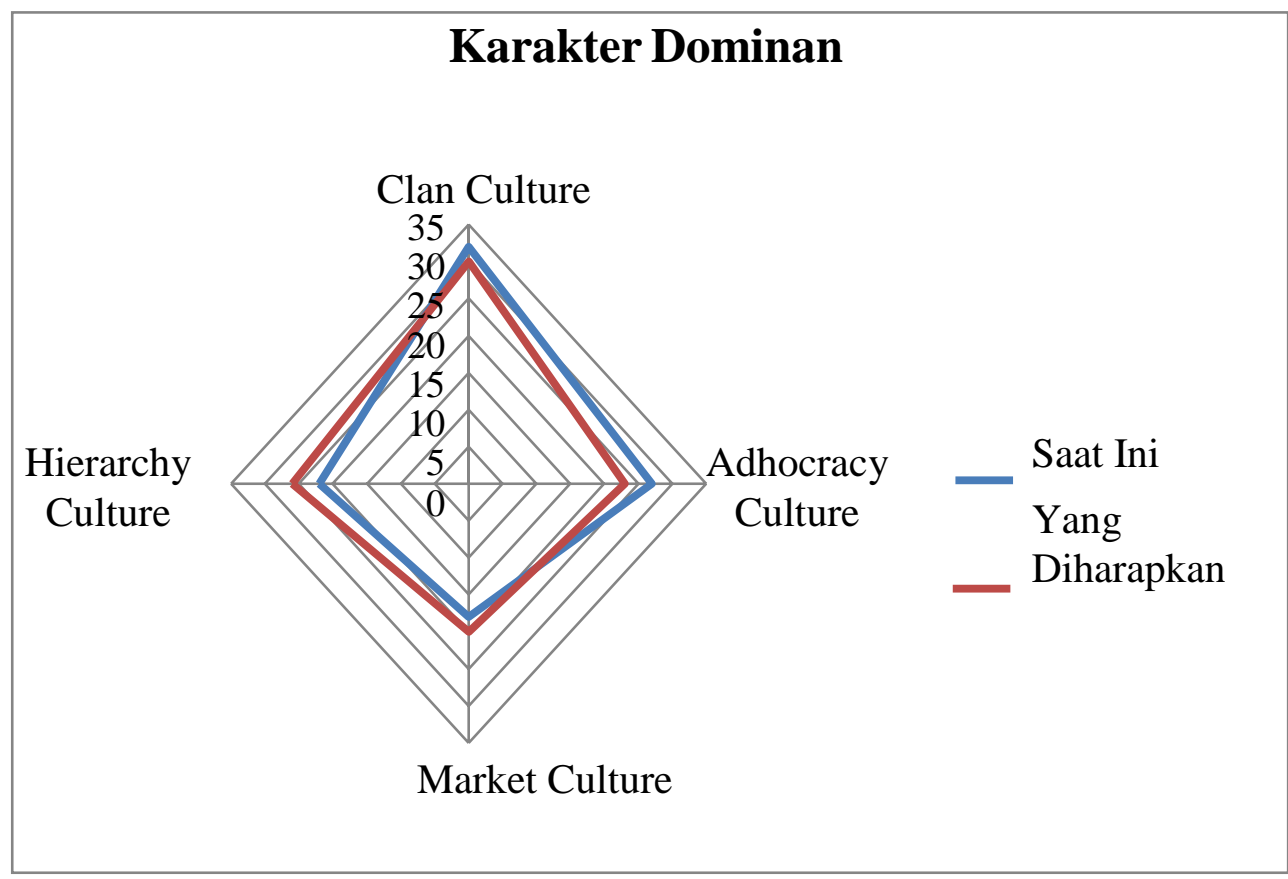

Gambar 3 : Karakter Dominan

Sumber : Data primer yang diolah, 2020 
Jurnal PRAXIS | Vol. 3 | No. 1 | September 2020

Berikut adalah daftar jawaban dari hasil wawancara peneliti dengan responden pada indikator karakter dominan yang mendukung temuan pada data diatas.

Tabel 1. Hasil Wawancara Indikator Karakter Dominan

\begin{tabular}{|c|c|}
\hline No. Responden & Jawaban Responden \\
\hline Responden 2 & Atlas n Co jadi rumah keduaku \\
\hline Responden 3 & Atlas n Co rumahku, temen2 keluarga sendiri. keakrabannya lebih terasa \\
\hline Responden 4 & $\begin{array}{l}\text { aku merasa seperti rumah kedua, teman seperti keluarga, atasan seperti } \\
\text { sahabat sendiri. }\end{array}$ \\
\hline Responden 5 & $\begin{array}{l}\text { Atlas n Co dianggap keluarga lah. Peraturannya ketet teman kerja seperti } \\
\text { keluarga. }\end{array}$ \\
\hline Responden 6 & Seperti keluarga sendiri rumah kedua. \\
\hline Responden 7 & $\begin{array}{l}\text { Kalau di atlas sih lebih ke kekeluargaan dan fleksibel, tidak ada gap } \\
\text { karyawan lama dengan yang baru. }\end{array}$ \\
\hline Responden 9 & $\begin{array}{l}\text { Atlas n Co menurut saya seperti keluarga, santai tapi tetep tanggung } \\
\text { jawab , komunikasinya baik, }\end{array}$ \\
\hline Responden 10 & $\begin{array}{l}\text { Karakternya Atlas sendiri lebih ke kekeluargaan dan tempat yang bebas } \\
\text { untuk berekspresi peraturan ketet. Masih memberikan kebebasan dan } \\
\text { mereka mengerti karakter pekerjanya itu masih anak-anak muda. }\end{array}$ \\
\hline Responden 13 & Atlas seperti keluarga, karyawannya juga bisa dibilang dekat, solid. \\
\hline Responden 14 & Atlas seperti rumah sendiri dan keluarga, teman2 dapat diajak kerja sama. \\
\hline Responden 15 & $\begin{array}{l}\text { Atlas lebih ke keluargaan, karena seperti rumah sendiri, bekerja ada } \\
\text { targetnya, kita disuruh menejualin sejumlah produk tertentu. }\end{array}$ \\
\hline \multicolumn{2}{|c|}{$\begin{array}{l}\text { Berdasarkan analisis kualitatif yang dilakukan menggunakan pertanyan terbuka yang } \\
\text { diberikan kepada karyawan Atlas n Co dengan menggabungkan kata atau kalimat yang mirip } \\
\text { ditemukan bahwa mayoritas karyawan Atlas n Co merasakan dan menginginkan suasana } \\
\text { nyaman, tenang dan solid layaknya keluarga dalam sebuah rumah dimana Atlas n Co juga } \\
\text { dirasakan sebagai rumah bagi karyawannya. Atlas n Co perlu untuk terus mempertahankan } \\
\text { agar budaya clan yang sudah sesuai dengan keinginan karyawan ini dapat terus berlangsung } \\
\text { guna meningkatkan rasa nyaman karyawan dalam bekerja. }\end{array}$} \\
\hline
\end{tabular}

Sumber : data primer yang diolah, 2020

Kesimpulannya, berdasarkan hasil kuesioner dan didukung dengan hasil wawancara menggunakan pertanyaan terbuka ditemukan bahwa karyawan Atlas n Co merasakan sekaligus menginginkan budaya clan menjadi karakteristik dominan di Atlas n Co. Hal ini juga mengartikan bahwa karyawan Atlas n Co merasakan 
Jurnal PRAXIS | Vol. 3 | No. 1 | September 2020

sekaligus menginginkan Atlas $\mathrm{n}$ Co sebagai tempat pribadi seperti rumah dan keluarga besar dengan karakter orang orangnya yang saling berbagi satu sama lain. Karena budaya yang dirasakan dan diharapkan sudah sesuai maka Atlas n Co perlu untuk mempertahankan budaya organisasi pada dimensi karakteristik dominan ini.

\section{b. Perbandingan profil budaya organisasi kepemimpinan organisasi pada saat ini dan yang diharapkan karyawan Atlas n Co}

Berikut adalah grafik budaya organisasi pada dimensi kepemimpinan organisasi pada saat ini dan yang diharapkan karyawan Atlas n Co :

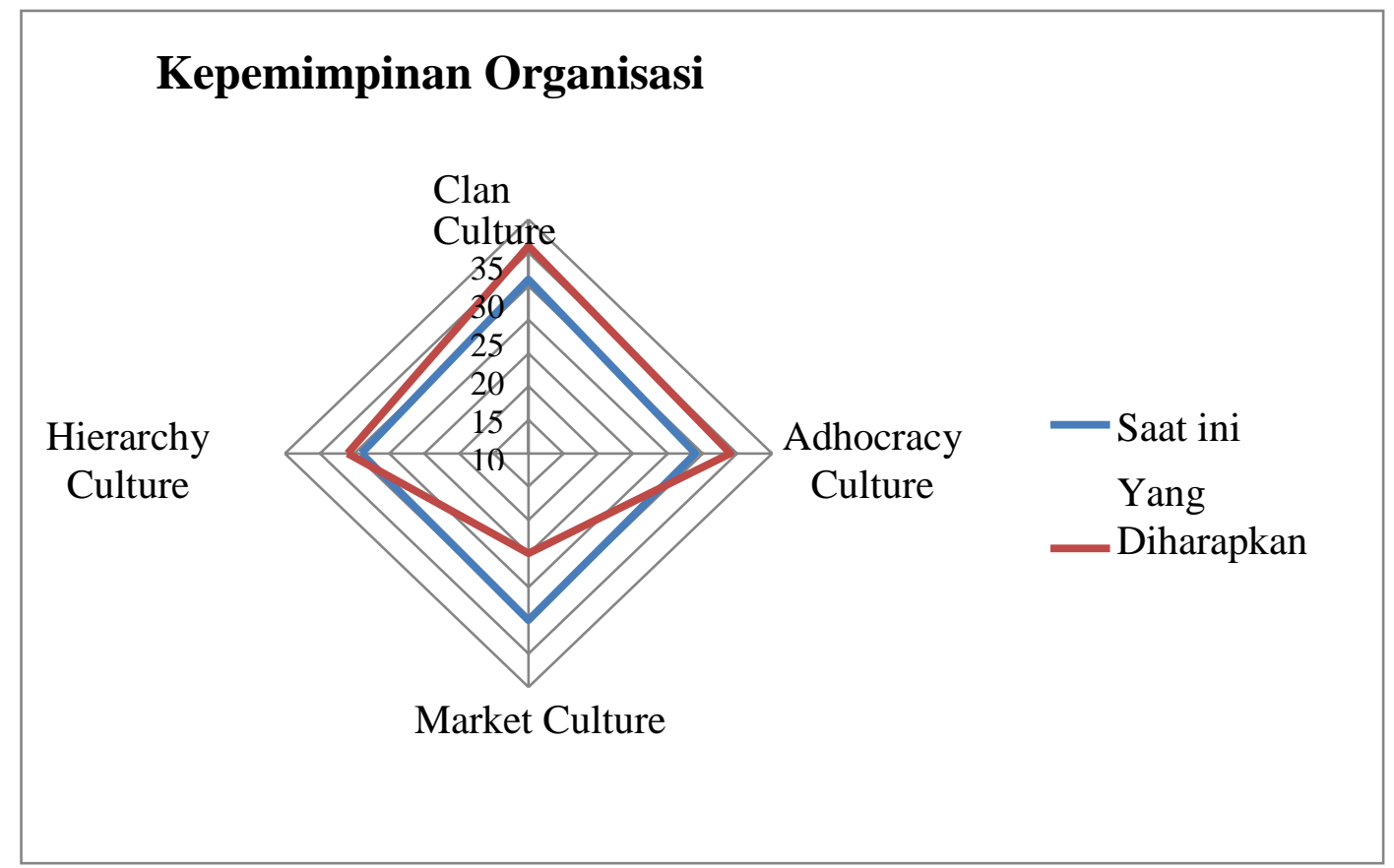

Gambar 4 : Kepemimpinan Organisasi

Sumber : Data primer yang diolah, 2020

Berdasarkan gambar diatas dapat diketahui bahwa skor clan culture pada budaya saat inimemperoleh skor tertinggi yaitu 26 yang ditunjukkan dengan garis berwarna biru yang menunjukkan bahwa saat ini karyawan Atlas n Co merasakan budaya clan yang sangat kuat pada dimensi kepemimpinan organisasi. Lalu pada harapannya karyawan Atlas $\mathrm{n}$ Co mengharapkan budaya clan tetap menjadi karakteristik kepemimpinan organisasi di coffee shopAtlas n Co dengan perolehan skor tertinggi pada clan culture yaitu 31 yang ditunjukkan dengan garis berwarna merah. Berdasarkan hasil tersebut dapat disimpulkan bahwa karyawan Atlas n Co merasakan sekaligus menginginkan kepemimpinan yang bersifat sebagai mentor dan fasilitator yang selalu memberikan bimbingan. 
Jurnal PRAXIS | Vol. 3 | No. 1 | September 2020

Berikut adalah daftar jawaban dari hasil wawancara peneliti dengan responden pada indikator kepemimpinan organisasi yang mendukung temuan pada data diatas :

Tabel 2 . Hasil Wawancara Indikator Kepemimpinan Organisasi

\begin{tabular}{|c|c|}
\hline No. Responden & Jawaban Responden \\
\hline Responden 1 & $\begin{array}{l}\text { Keputusan harus sama Semarang dan Jakarta, baru jalan, kalau belum } \\
\text { sepakat kita menunggu agak lama, kadang kala jobfull. }\end{array}$ \\
\hline Responden 2 & $\begin{array}{l}\text { Kalau pemiliknya satu orang keputusannya cepat, tapi kalau } 2 \text { orang cukup } \\
\text { lama. }\end{array}$ \\
\hline Responden 3 & $\begin{array}{l}\text { Kalau untuk mas beva sudah seperti mentor, selalu ngajarin, kalau ada yang } \\
\text { salah, memberi contoh untuk cara kerjanya. }\end{array}$ \\
\hline Responden 4 & Koordinator dan mentor. \\
\hline Responden 5 & $\begin{array}{l}\text { Head bar kurang membaur kalau sekarang di Atlas n Co.,untuk mentor } \\
\text { masih belum. }\end{array}$ \\
\hline Responden 10 & $\begin{array}{l}\text { Kepemimpinan terlalu longgar, peraturan tertulis dan tidak tertulis belum } \\
\text { dijalankan dengan tegas, melanggar ada sanksi, banyak toleransinya tidak } \\
\text { seperti yang kuharapkan. }\end{array}$ \\
\hline Responden 13 & $\begin{array}{l}\text { Kepemimpinannya banyak toleransinya. Ada kelonggaran misal barang rusak } \\
\text { ketidak sengaja, atau mungkin terlambat ada toleransinya dan beberapa hal } \\
\text { lain }\end{array}$ \\
\hline Responden 14 & $\begin{array}{l}\text { Perlu diperbaiki perihal kepemimpinan di Atlas n Co, sudah sesuai keinginan } \\
\text { apa belum ya sudah lumayan. }\end{array}$ \\
\hline \multicolumn{2}{|c|}{$\begin{array}{l}\text { Berdasarkan analisis kualitatif yang dilakukan menggunakan pertanyan terbuka yang } \\
\text { diberikan kepada karyawan Atlas n Co dengan menggabungkan kata atau kalimat yang mirip } \\
\text { ditemukan bahwa mayoritas karyawan Atlas n Co merasakan karakter kepemimpinan yang } \\
\text { belum secara spesifik sesuai keinginan karena kepemimpinan di Atlas n Co yang } \\
\text { dirasakan oleh karyawan saat ini bersifat longgar atau banyak memberi toleransi, serta sebagai } \\
\text { fasilitator yang baik namun belum menjadi sosok mentor yang baik. Beberapa karyawan juga } \\
\text { menyayangkan garis koordinasi yang rumit sehingga tingkat responsivitas pemimpin dalam } \\
\text { menanggapi masalah yang dilaporkan oleh karyawan rendah, lambat dalam menangani. Meskipun } \\
\text { demikian, karyawan Atlas n Co mengharapkan karakter kepemimpinan clan tetap menjadi karakter } \\
\text { kepemimpinan di Atlas n Co yang artinya karyawan Atlas n Co masih berharap adanya perbaikan } \\
\text { dari sisi kepemimpinan di Atlas n Co untuk menjadi lebih baik lagi dan sesuai dengan apa yang } \\
\text { mereka harapkan. }\end{array}$} \\
\hline
\end{tabular}

Sumber : data primer yang diolah, 2020

Kesimpulannya, berdasarkan hasil kuesioner dan didukung dengan hasil wawancara menggunakan pertanyaan terbuka ditemukan bahwa karyawan Atlas n Co merasakan sekaligus menginginkan budaya clan menjadi karakteristik kepemimpinan organisasi di Atlas n Co. Hal ini juga mengartikan bahwa karyawan 
Jurnal PRAXIS | Vol. 3 | No. 1 | September 2020

Atlas $\mathrm{n}$ Co merasakan sekaligus menginginkan kepemimpinan yang bersifat sebagai mentor dan fasilitator yang selalu memberikan bimbingan. Karena budaya yang dirasakan dan diharapkan sudah sesuai maka Atlas n Co perlu untuk mempertahankan budaya organisasi pada dimensi kepemimpinan organisasi ini.

\section{c. Perbandingan profil budaya organisasi dimensi manajemen personil pada saat ini dan yang diharapkan karyawan Atlas n Co}

Berikut adalah grafik budaya organisasi pada dimensi manajemen personil di saat ini dan yang diharapkan karyawan Atlas n Co :

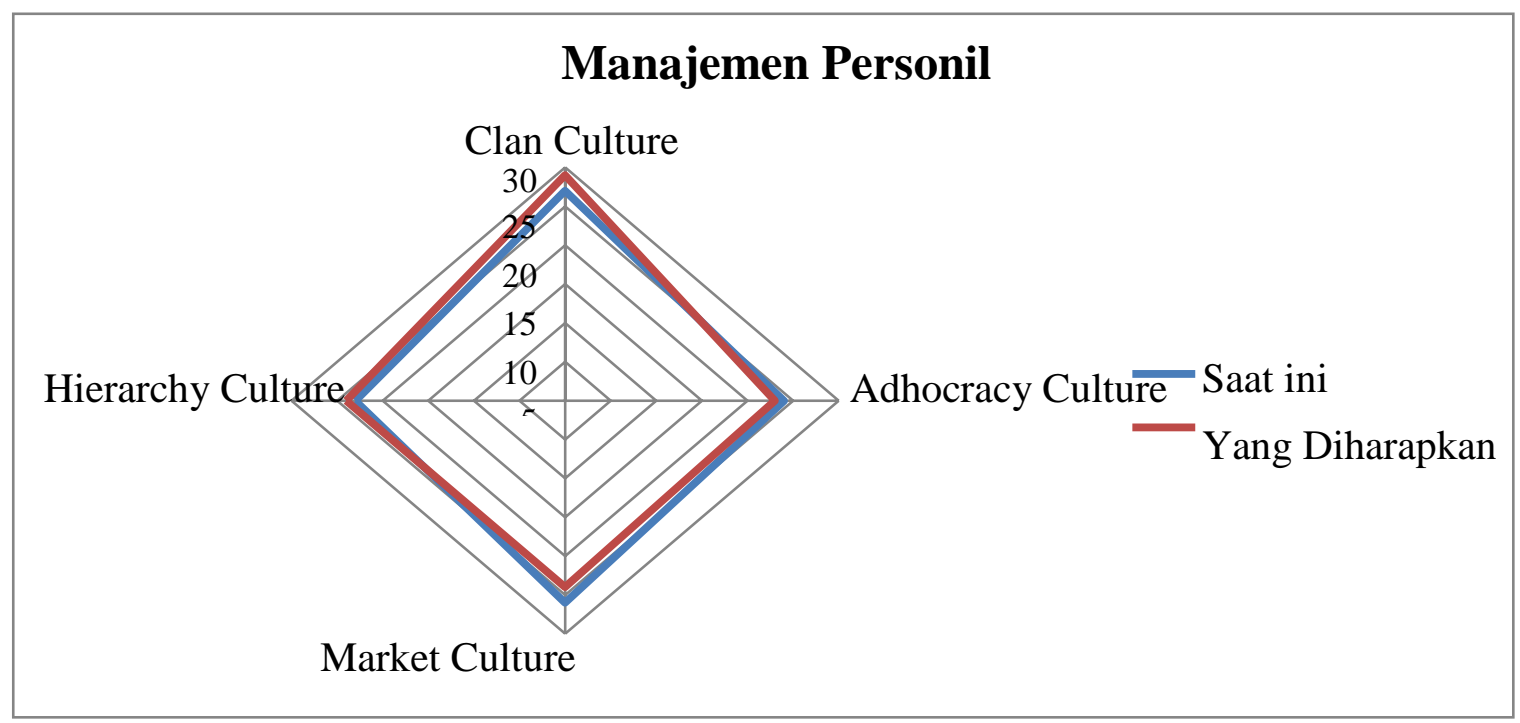

Gambar 5: Manajemen Personil

Sumber : Data primer yang diolah, 2020

Berdasarkan gambar diatas dapat diketahui bahwa skor pada clan culture saat ini mendapatkan skor tertinggi yaitu 27 yang ditunjukkan dengan garis berwarna biru yang menunjukkan bahwa saat ini karyawan Atlas n Co merasakan budaya clan yang sangat kuat pada dimensi manajemen personil. Lalu pada harapannya juga karyawan Atlas n Co mengharapkan budaya clan tetap menjadi karakter manajemen personil di coffee shopAtlas n Co yang juga dapat dilihat pada garis merah pada gambar diatas dimana clan culture juga mendapatkan skor tertinggi yaitu 29. Berdasarkan hasil tersebut dapat disimpulkan bahwa karyawan Atlas n Co merasakan Atlas n Co sebagai organisasi yang bercirikan kerja tim, kesepakatan (konsesus), dan partisipatif. 
Berikut adalah daftar jawaban dari hasil wawancara peneliti dengan responden pada indikator menejemen personil yang mendukung temuan pada data diatas :

\section{Tabel 3. Hasil Wawancara Indikator Manajemen Personil}

\begin{tabular}{|c|c|}
\hline No. Responden & Jawaban Responden \\
\hline Responden 2 & Kompak dan so far atlas ngerangkul anak baru. \\
\hline Responden 3 & $\begin{array}{l}\text { Menejemennya Atlas n Co bercirikan kerja tim, ada SOP dan mandiri juga } \\
\text { bisa. }\end{array}$ \\
\hline Responden 4 & Yo kerja tim sih menurutku \\
\hline Responden 6 & $\begin{array}{l}\text { kerjasama tim,bisa koordinasi antar karyawan entah ke sesama barista, atau } \\
\text { barista dan kitchen, dengan atasan juga, manajemennnya bersifat partisipatif }\end{array}$ \\
\hline Responden 9 & $\begin{array}{l}\text { Diutamakan kerjasama antar karyawan, antara kitchen sama bar tetep harus } \\
\text { solid. }\end{array}$ \\
\hline Responden 10 & $\begin{array}{l}\text { kerja tim lebih ke keluarga tapi belum menjadi kompetitif buat sesama } \\
\text { pekerjanya. }\end{array}$ \\
\hline Responden 13 & $\begin{array}{l}\text { toleransi cukup besar juga bebas berkarya } \\
\text { diluar pekerjaannya karena disini juga sebagai tempat kolektif art di } \\
\text { Semarang }\end{array}$ \\
\hline \multicolumn{2}{|c|}{$\begin{array}{l}\text { Berdasarkan analisis kualitatif yang dilakukan menggunakan pertanyaan terbuka yang } \\
\text { diberikan kepada karyawan Atlas n Co dengan menggabungkan kata atau kalimat yang mirip } \\
\text { ditemukan bahwa mayoritas karyawan Atlas n Co merasakan dan menginginkan karakter } \\
\text { manajemen personil yang bercirikan kerja tim yang solid antar karyawan yang juga diikuti } \\
\text { dengan keterlibatan karyawan dalam pengambilan keputusan dan hal - hal yang terkait } \\
\text { dengan operasional dan sebagainya berdasar kesepakatan atau konsesus. Hal ini terlihat saat } \\
\text { peneliti sedang mengambil data dengan membagi kuisioner saat jam pergantian shift dimana } \\
\text { pemimpin Atlas n Co rutin mengadakan briefing pergantian shift dan sharing masalah dan } \\
\text { masukan sekaligus menghimpun pendapat dari karyawan untuk kemajuan Atlas n Co. } \\
\text { Karyawan Atlas n Co juga menginginkan dan merasakan budaya yang partisipatif yang } \\
\text { berarti pihak manajemen juga perlu untuk mempertahankan apa yang sudah ada sekarang } \\
\text { yaitu budaya yang bercirikan kerja tim, berdasarkan kesepakatan dan partisipatif. }\end{array}$} \\
\hline
\end{tabular}

Sumber : data primer yang diolah, 2020

Kesimpulannya, berdasarkan hasil kuesioner dan didukung dengan hasil wawancara menggunakan pertanyaan terbuka ditemukan bahwa karyawan Atlas $\mathrm{n}$ Co merasakan sekaligus menginginkan budaya clan menjadi karakteristik manajemen personil di Atlas n Co. Hal ini juga mengartikan bahwa karyawan Atlas $\mathrm{n}$ Co merasakan sekaligus menginginkan 
Jurnal PRAXIS | Vol. 3 | No. 1 | September 2020

karakteristik manajemen personil yang bercirikan kerja tim, berdasarkan pada kesepakatan (konsesus) dan partisipatif. Karena budaya yang dirasakan dan diharapkan sudah sesuai maka Atlas $\mathrm{n}$ Co perlu untuk mempertahankan budaya organisasi pada dimensi manajemen personil ini.

\section{d. Perbandingan profil budaya organisasi dimensi perekat organisasi pada saat ini dan yang diharapkan karyawan Atlas n Co}

Berikut adalah grafik budaya organisasi pada dimensi perekat organisasi pada saat ini dan yang diharapkan karyawan Atlas n Co :

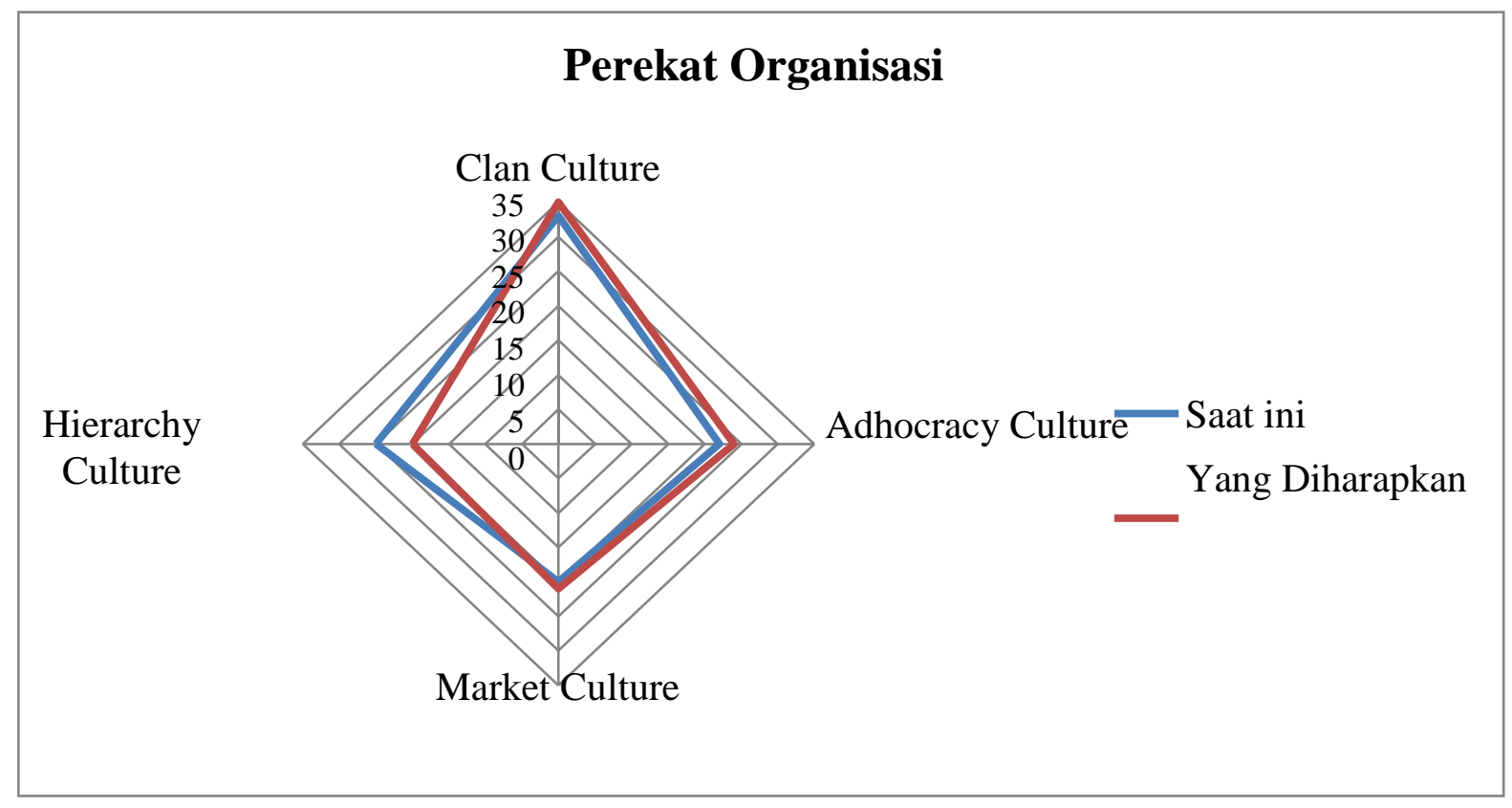

Gambar 6 : Perekat Organisasi

Sumber : Data primer yang diolah, 2020

Berdasarkan gambar diatas dapat diketahui bahwa skor pada clan culture saat ini mendapatkan skor tertinggi yaitu 33 yang ditunjukkan dengan garis berwarna biru yang menunjukkan bahwa saat ini karyawan Atlas n Co merasakan budaya clan yang sangat kuat pada dimensi perekat organisasi. Lalu pada harapannya juga karyawan Atlas n Co mengharapkan budaya clan tetap menjadi perekat organisasi di coffee shopAtlas n Co yang juga dapat dilihat pada garis berwarna merah pada gambar diatas dimana clan culture juga mendapatkan skor tertinggi yaitu 35. Karyawan Atlas n Co merasakan serta menginginkan Atlas n Co sebagai tempat atau organisasi yang dilandaskan kepercayaan dan komitmen yang sangat dipegang teguh. 
Jurnal PRAXIS | Vol. 3 | No. 1 | September 2020

Berikut adalah daftar jawaban dari hasil wawancara peneliti dengan responden pada indikator perekat organisasi yang mendukung temuan pada data diatas :

Tabel.4. Hasil Wawancara Indikator Perekat Organisasi

\begin{tabular}{|c|c|}
\hline No. Responden & Jawaban Responden \\
\hline Responden 1 & ada interest atau minat yang sama \\
\hline Responden 3 & $\begin{array}{l}\text { Perekatnya diadakan General Cleaning, berguna untuk memupuk rasa } \\
\text { kekeluargaan, saling membantu, ada acara barsama }\end{array}$ \\
\hline Responden 4 & Yang pertama kesetiaan dengan apa \\
\hline Responden 5 & $\begin{array}{l}\text { Kesamaan karyawan otomatis dengan banyak keluhan yang sama terhadap } \\
\text { pengelolaannya jadi bersatu,. ada apa-apa diomongin dulu. faktor usia juga } \\
\text { karena kita kan masih sepantaran }\end{array}$ \\
\hline Responden 6 & Saling percaya dan membantu kalau ada yang kesusahan. \\
\hline Responden 7 & Kekeluargaannya \\
\hline Responden 8 & $\begin{array}{l}\text { Perekat antar karyawan di Atlas n Co adalah kekeluargaan, merupakan } \\
\text { rumah kedua, bebas berinteraksi dengan customer, dengan teman-teman }\end{array}$ \\
\hline Responden 9 & Antar karyawan bisa dekat, adanya kesamaan komitmen. \\
\hline Responden 10 & kepercayaan dan komitmen sama fokus hal paling mutakhir. \\
\hline Responden 11 & Kecocokan hobi, kesukaan, kepercayaan. \\
\hline Responden 12 & Lebih ke kepercayaan antar karyawannya \\
\hline Responden 14 & Rasa keluarga jadi saling percaya, saling bantu dan solid \\
\hline Responden 15 & $\begin{array}{l}\text { Saling percaya dalam perjaan. Terus juga anak-anak interest sama dan } \\
\text { sharing bersama. }\end{array}$ \\
\hline \multicolumn{2}{|c|}{$\begin{array}{l}\text { Berdasarkan analisis kualitatif yang dilakukan menggunakan pertanyan terbuka yang } \\
\text { diberikan kepada karyawan Atlas n Co dengan menggabungkan kata atau kalimat yang mirip } \\
\text { ditemukan bahwa mayoritas karyawan Atlas n Co saat ini merasakan budaya clan sekaligus } \\
\text { mengharapkan budaya clan tetap menjadi perekat organisasidi Atlas n Co. Karyawan Atlas n } \\
\text { Co saat ini merasakan sekaligus menginginkan budaya yang saling percaya satu sama lain } \\
\text { dalam pekerjaannya yang juga berdasarkan komitmen satu sama lain untuk saling membantu. } \\
\text { Hal ini berarti apa yang diinginkan sudah tercapai karena nilai - nilai pada budaya clan juga } \\
\text { sudah dirasakan pada saat ini dan perlu adanya tindakan untuk mempertahankan agar dapat } \\
\text { dimanfaatkan guna mendapatkan hasil yang maksimal bagi coffee shop Atlas n Co } \\
\text { kedepannya. }\end{array}$} \\
\hline
\end{tabular}

Sumber : data primer yang diolah, 2020 
Jurnal PRAXIS | Vol. 3 | No. 1 | September 2020

Kesimpulannya, berdasarkan hasil kuesioner dan didukung dengan hasil wawancara menggunakan pertanyaan terbuka ditemukan bahwa karyawan Atlas $\mathrm{n}$ Co merasakan sekaligus menginginkan budaya clan menjadi perekat organisasi di Atlas $n$ Co. Hal ini juga mengartikan bahwa karyawan Atlas $\mathrm{n}$ Co merasakan sekaligus menginginkan Atlas $\mathrm{n}$ Co sebagai tempat atau organisasi yang dilandaskan kepercayaan dan komitmen yang sangat dipegang teguh. Hal ini sekaligus menunjukkan bahwa pada dimensi perekat organisasi di Atlas n Co yang saat ini terjadi sudah sesuai dengan apa yang diharapkan oleh karyawan yang artinya pihak manajemen Atlas $n$ Co perlu mempertahankan dan memanfaatkan kondisi yang sudah sesuai dengan harapan ini.

\section{e. Perbandingan profil budaya organisasi dimensi strategi yang ditekkankan pada saat ini dan yang diharapkan karyawan Atlas n Co}

Berikut adalah grafik budaya organisasi pada dimensi strategi yang ditekankan pada saat ini dan yang diharapkan karyawan Atlas n Co :

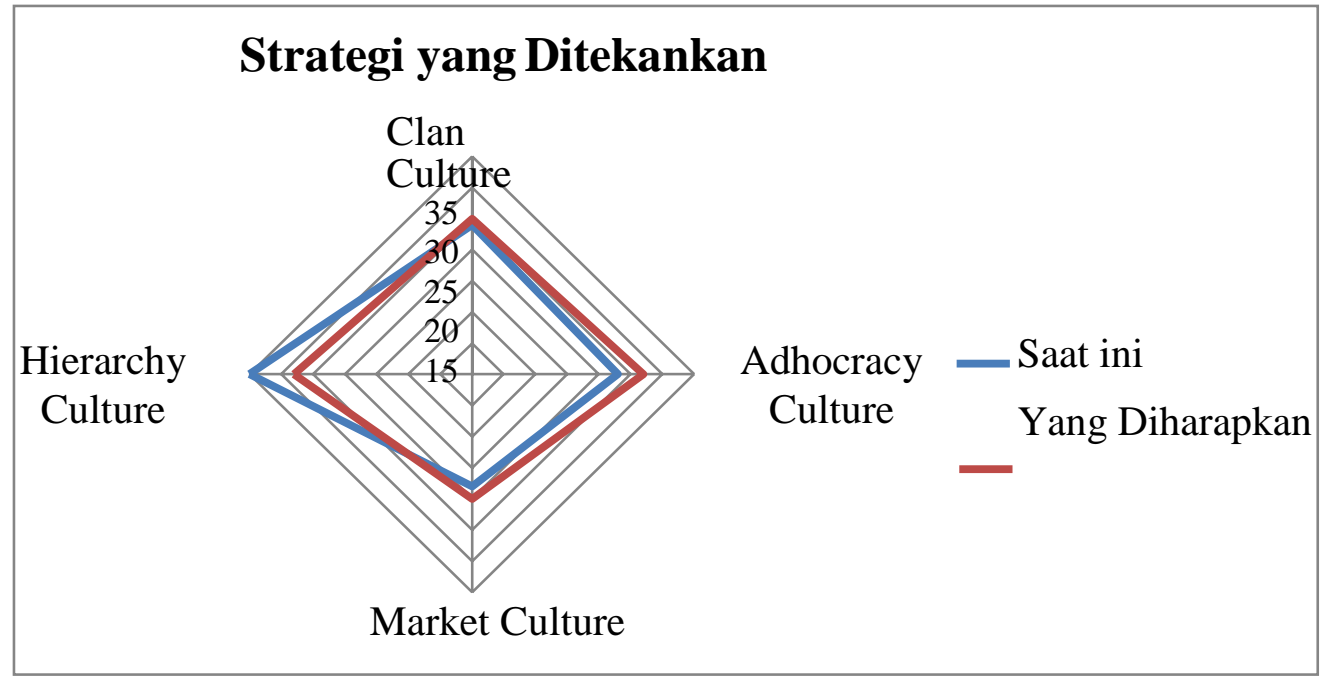

Gambar 7 : Strategi yang Ditekankan

Sumber : Data primer yangdiolah, 2020

Berdasarkan gambar diatas dapat diketahui bahwa skor pada hierarchyculture saat ini mendapatkan skor tertinggi yaitu 35 yang ditunjukkan dengan garis berwarna biru yang menunjukkan bahwa saat ini karyawan Atlas $\mathrm{n}$ Co merasakan budaya hierarchy yang sangat kuat pada dimensi strategi yang ditekankan, berbeda dengan dimensi yang lain yang rata - rata didominasi oleh clan culture. Lalu pada harapannya juga karyawan Atlas n Co mengharapkan budaya hierarchy tetap menjadi karakteristik strategi ditekankan di coffee shopAtlas $\mathrm{n}$ Co yang juga dapat dilihat pada garis merah pada gambar diatas dimana hierarchy culture juga mendapatkan skor tertinggi yaitu 28. Berdasarkan hasil tersebut dapat disimpulkan bahwa pada dimensi strategi yang ditekankan di Atlas n Co yang saat ini terjadi sudah sesuai dengan apa yang 
Jurnal PRAXIS | Vol. 3 | No. 1 | September 2020

diharapkan oleh karyawan Atlas n Co. Hal ini juga menunjukkan bahwa pada penerapan strategi di coffee shop Atlas $\mathrm{n}$ Co sangat berfokus pada ketahanan dan stabilitas pada produk yang ditawarkan.
Selain itu dalam penerapan strateginya karyawan dituntut untuk efisien dalam menggunakan bahan baku yang juga bertujuan untuk menghemat pengeluaran perusahaan.

Berikut adalah daftar jawaban dari hasil wawancara peneliti dengan responden pada indikator strategi yang ditekankan yang mendukung temuan pada data diatas:

Tabel 5. Hasil Wawancara Indikator Strategi yang Ditekankan

\begin{tabular}{|c|c|}
\hline No.Responden & Jawaban Responden \\
\hline Responden 3 & $\begin{array}{l}\text { Atlas n Co itu menuntut untuk mengembangkan SDM, bagian Kitchen ada } \\
\text { menu baru kita masak bareng terus saling nyobain gimana rasanya enak apa } \\
\text { enggak. Jadi karyawannya diikut sertakan }\end{array}$ \\
\hline Responden 4 & Efisiensi menghemat isiensi sih? \\
\hline Responden 6 & $\begin{array}{l}\text { kita lebih dituntut efisien menekankan kepada keuntungan, kompetisi antar } \\
\text { karyawan tidak }\end{array}$ \\
\hline Responden 7 & Efisiensi, kalau kompetisi karyawan aku rasa tidak. \\
\hline Responden 9 & $\begin{array}{l}\text { Kalo dari Atlas } \mathrm{n} \text { Co lebih dituntut efisien dalam melakukan pekerjaan } \\
\text { supaya strateginya dapat berjalan }\end{array}$ \\
\hline Responden 13 & $\begin{array}{l}\text { Lebih ke efisiensi, karena disini kita dituntut untukhemat bahan baku untuk } \\
\text { menekan angka produksi biar gak boros. }\end{array}$ \\
\hline \multicolumn{2}{|c|}{$\begin{array}{l}\text { Berdasarkan analisis kualitatif yang dilakukan menggunakan pertanyan terbuka yang } \\
\text { diberikan kepada karyawan Atlas } n \text { Co dengan menggabungkan kata atau kalimat yang mirip } \\
\text { ditemukan bahwa mayoritas karyawan Atlas n Co saat ini merasakan budaya hierarchy yang } \\
\text { sangat kuat sekaligus menginginkan budaya hierarchy tetap menjadi karakteristik Atlas n Co } \\
\text { dalam penerapan strateginya. Berdasarkan hasil wawancara ditemukan bahwa budaya } \\
\text { hierarchy yang dimaksud adalah budaya yang mengedepankan pada efisiensi produk. Karena } \\
\text { dalam hal ini Atlas n Co adalah perusahaan Food and Beverage artinya produk yang dijual } \\
\text { adalah makanan dan minuman dan yang menjadi subjek efisiensi adalah bahan baku } \\
\text { pembuatan makanan dan minuman tersebut, disusul dengan perabotan cafe yang juga harus } \\
\text { dijaga agar awet dan bertahan lama. }\end{array}$} \\
\hline
\end{tabular}

Sumber : data primer yang diolah, 2020

Kesimpulannya, berdasarkan hasil kuesioner dan didukung dengan hasil wawancara menggunakan pertanyaan terbuka ditemukan bahwa karyawan Atlas $\mathrm{n}$ Co merasakan sekaligus menginginkan budaya hierarchy menjadi karakteristik penekanan strategi di Atlas n Co. Hal ini juga mengartikan bahwa karyawan Atlas $n$ Co merasakan sekaligus menginginkan penekanan strategi yang sangat berfokus 
Jurnal PRAXIS | Vol. 3 | No. 1 | September 2020

pada ketahanan dan stabilitas pada produk yang ditawarkan. Selain itu dalam penerapan strateginya karyawan dituntut untuk efisien dalam menggunakan bahan baku yang juga bertujuan untuk menghemat pengeluaran perusahaan dimana hal itu juga mendukung kelancaran operasional yang dikontrol ketat oleh koordinator tim seperti head barista, head kitchen dan manajer. Hal ini sekaligus menunjukkan bahwa pada dimensi strategi yang ditekankan di Atlas n Co yang saat ini terjadi sudah sesuai dengan apa yang diharapkan oleh karyawan yang artinya pihak manajemen Atlas $\mathrm{n}$ Co perlu mempertahankan dan memanfaatkan kondisi yang sudah sesuai dengan harapan ini.

\section{f. Perbandingan profil budaya organisasi dimensi kriteria keberhasilan pada saat ini dan yang diharapkan karyawan Atlas n Co}

Berikut adalah grafik budaya organisasi pada dimensi kriteria keberhasilan pada saat ini dan yang diharapkan karyawan Atlas n Co :

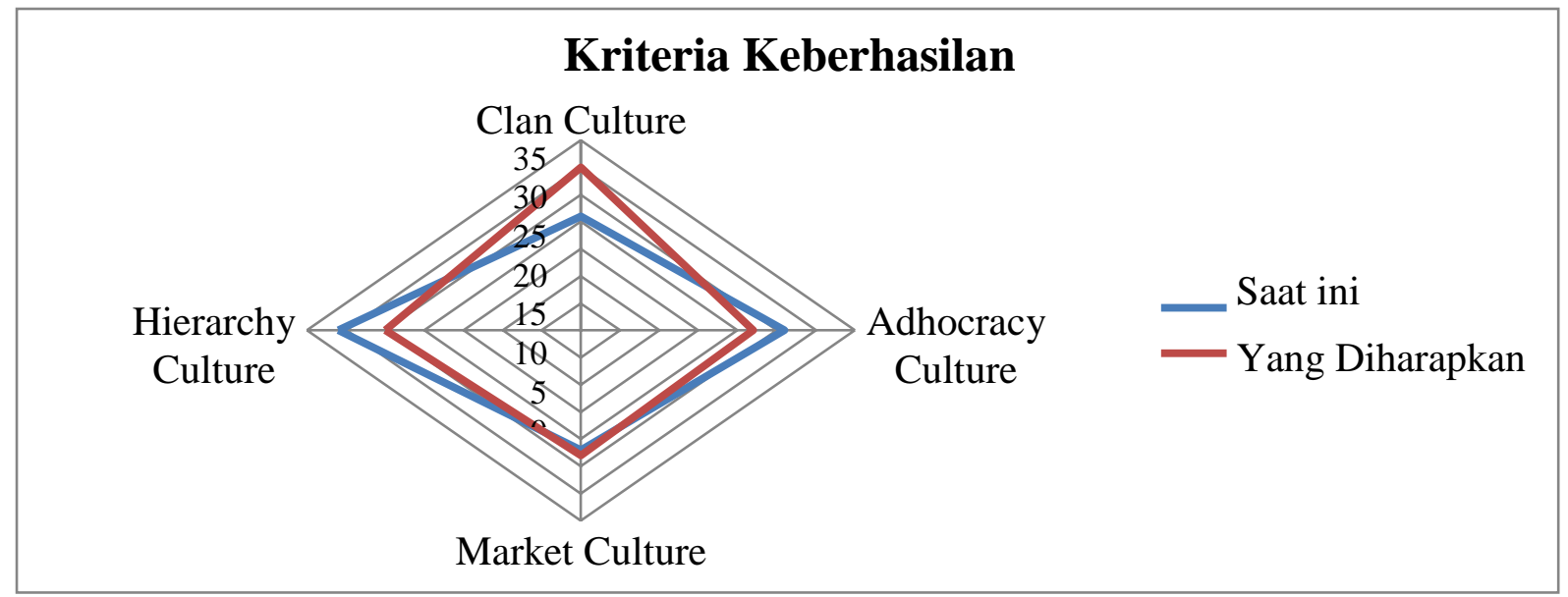

\section{Gambar 8 : Kriteria Keberhasilan}

Sumber : Data primer yang diolah, 2020

Berdasarkan gambar diatas dapat diketahui bahwa skor pada hierarchy culture di budaya yang saat ini dirasakan mendapatkan skor tertinggi yaitu 31 yang ditunjukkan dengan garis berwarna biru yang menunjukkan bahwa saat ini karyawan Atlas n Co merasakan budaya hierarchy yang sangat kuat pada dimensi kriteria keberhasilan. Hal ini mendefinisikan bahwa Atlas n Co menekankan keberhasilan pada karyawannya berdasarkan efisiensi, produk dan jasa yang dapat diandalkan dengan pelayanan yang baik dan melakukan proses produksi dan operasional dengan biaya atau ongkos yang rendah. Sedangkan yang diinginkan karyawan adalah budaya clan yang menjadi kriteria keberhasilan di coffee shop Atlas n Co. Hal ini dapat dilihat bahwa pada budaya yang diharapkan, budaya clan mendapatkan skor tertinggi sebesar 30 yang ditunjukkan dengan garis berwarna merah pada gambar yang artinya karyawan Atlas n Co menginginkan kriteria keberhasilan yang mendefinisikan sukses atas dasar pengembangan SDM, kerja tim, komitmen karyawan dan kepedulian perusahaan pada karyawan. 
Berikut adalah daftar jawaban dari hasil wawancara peneliti dengan responden pada indikator kriteria keberhasilan yang mendukung temuan pada data diatas :

Tabel 6. Hasil Wawancara Indikator Kriteria Keberhasilan

\begin{tabular}{|c|c|}
\hline No.Responden & Jawaban Responden \\
\hline Responden 3 & $\begin{array}{l}\text { aku di kitchen. dianggap berhasil kalau ada pesenan masakanku rasanya } \\
\text { udah sesuai standard dan pas. }\end{array}$ \\
\hline Responden 4 & $\begin{array}{l}\text { Melakukan SOP dengan baik dan benar, terlalu banyak drama makanya aku } \\
\text { melakukan sesuai SOP }\end{array}$ \\
\hline Responden 5 & $\begin{array}{l}\text { Menurutku lebih mengikuti SOP dengan baik jadi lebih melakukan } \\
\text { tanggung jawab dengan benar. }\end{array}$ \\
\hline Responden 12 & $\begin{array}{l}\text { Tidak telat, lebih peka terhadap yang dilihat seperti mengambil gelas dan } \\
\text { piring yang kotor. Kebersihan dapur perlu diperhatikan. }\end{array}$ \\
\hline Responden 13 & $\begin{array}{l}\text { Lebih ke peraturan. Disini juga tidak pernah memberi reward. Untuk } \\
\text { sekedar pujian jarang jadi aku dipuji karena cukup cepat dalam adaptasi saat } \\
\text { masih baru. mengikuti peraturan dengan baik dan tidak dapat teguran aku } \\
\text { rasa cukup dikatakan berhasil. }\end{array}$ \\
\hline Responden 14 & $\begin{array}{l}\text { aku bisa menjual produk sesuai target yang ditetapkan. Dalam beberapa } \\
\text { situasi ada produk yang jarang keluar, dan bahannya hampir habis masa } \\
\text { penggunaannya, mau gak mau kita harus bisa menjual produk itu sebelum } \\
\text { kadaluarsa karena kalau sampai bahannya kadaluarsa dan dibuang kita rugi. } \\
\text { Aku dikatakan berhasil kalau bisa menjual produk tersebut dan menghindari } \\
\text { kerugian }\end{array}$ \\
\hline Responden 15 & $\begin{array}{l}\text { Aku dianggap berhasil disini tidak ada reward untuk karyawan Tapi } \\
\text { beberapa kali dapet pujian kecil gitkarena melaksanakan job desk dengan } \\
\text { baik. }\end{array}$ \\
\hline \multicolumn{2}{|c|}{$\begin{array}{l}\text { Berdasarkan analisis kualitatif yang dilakukan menggunakan pertanyan terbuka yang } \\
\text { diberikan kepada karyawan Atlas n Co dengan menggabungkan kata atau kalimat yang mirip } \\
\text { ditemukan bahwa mayoritas karyawan Atlas n Co saat ini merasakan budaya hierarchy yaitu } \\
\text { budaya yang menekankan keberhasilan pada efisiensi, produk dan jasa yang sesuai dengan } \\
\text { standar yang telah ditetapkan, dan ongkos produksi dan operasional yang rendah. Menurut } \\
\text { karyawan Atlas n Co, dasar keberhasilan juga diukur dari kepatuhan terhadap peraturan dan } \\
\text { SOP yang berlaku. Sedangkan pada harapannya karyawan menginginkan budaya clanmenjadi } \\
\text { dasar kriteria keberhasilan di Atlas n Co yang mendefinisikan sukses pada perkembangan } \\
\text { SDM, kerja tim, komitmen karyawan dan kepedulian antar karyawan. }\end{array}$} \\
\hline
\end{tabular}

Sumber : data primer yang diolah, 2020

Kesimpulannya, berdasarkan hasil kuesioner dan didukung dengan hasil wawancara menggunakan pertanyaan terbuka ditemukan bahwa karyawan Atlas 
Jurnal PRAXIS | Vol. 3 | No. 1 | September 2020

n Co merasakan budaya hierarchy menjadi kriteria keberhasilan di Atlas n Co. Sedangkan untuk harapannya karyawan Atlas $\mathrm{n}$ Co menginginkan budaya clan menjadi kriteria keberhasilan di Atlas n Co. Hal ini mengartikan bahwa karyawan Atlas n Co saat inimerasakanAtlas n Co menekankan keberhasilan pada karyawannya berdasarkan efisiensi, produk dan jasa yang dapat diandalkan dengan pelayanan yang baik dan melakukan proses produksi dan operasional dengan biaya atau ongkos yang rendah. Sedangkan untuk harapannya karyawan Atlas $\mathrm{n}$ Co menginginkan kriteria keberhasilan yang mendefinisikan sukses atas dasar pengembangan SDM, kerja tim, komitmen karyawan dan kepedulian perusahaan pada karyawan. Dengan demikian, coffee shop Atlas n Co perlu segera menyesuaikan apa yang saat ini dirasakan oleh karyawan dengan apa yang diinginkan oleh karyawan agar dapat mencapai hasil yang maksimal.

\section{g. Perbandingan profil budaya organisasi pada saat ini dan yang diharapkan karyawan Atlas n Co}

Berikut adalah grafik budaya organisasi pada saat ini dan yang diharapkan karyawan Atlas $n$ Co :

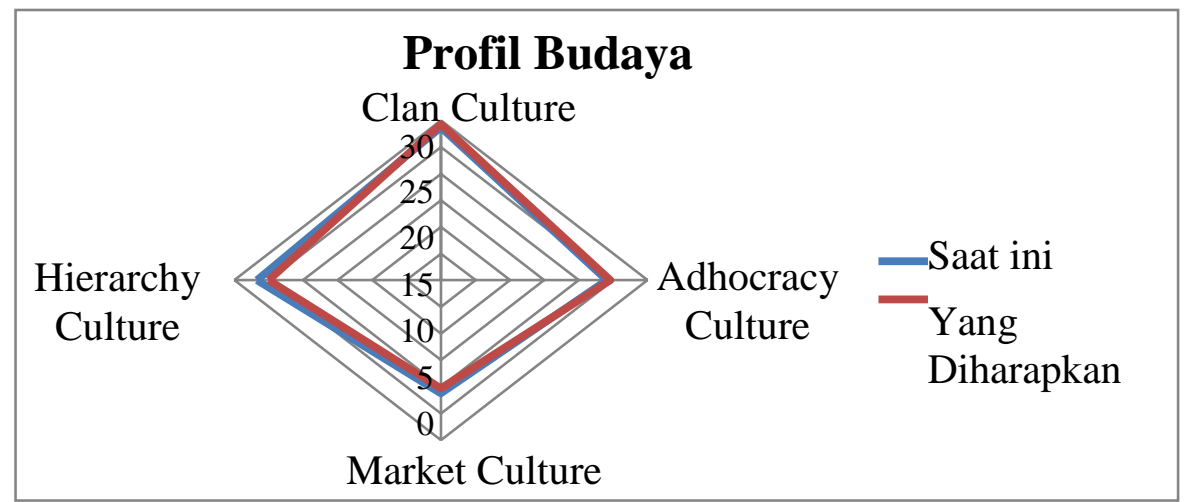

Gambar 9 : Budaya Organisasi

Sumber: Data primer yang diolah,2020

Berdasarkan gambar diatas dapat diketahui bahwa skor pada clan culture saat ini mendapatkan skor tertinggi yaitu 28,72 yang ditunjukkan dengan garis berwarna biru yang menunjukkan bahwa saat ini karyawan Atlas n Co merasakan budaya clan yang sangat kuat. Lalu pada harapannya karyawan Atlas n Co juga menginginkan budaya clan tetap menjadi budaya yang dominan di Atlas n Co, hal ini dapat terlihat pada garis merah digambar dimana clan culturemendapatkan skor tertinggi juga yaitu 29,3. Hasil ini menunjukkan bahwa budaya yang dirasakan karyawan Atlas n Co sudah selaras dengan budaya yang diinginkan yaitu budaya clan dimana skor pada budaya yang saat ini dan budaya yang diharapkan sama - sama mendapatkan skor tertinggi. Hal ini juga mendefinisikan bahwa saat ini karyawan Atlas $\mathrm{n}$ Co merasakan sekaligus menginginkan kebersamaan dan kekeluargaan dalam bekerja dengan karakter pemimpin yang bercirikan sebagai mentor atau ayah seperti didalam keluarga yang selalu berusaha 
Jurnal PRAXIS | Vol. 3 | No. 1 | September 2020

untuk mencapai mufakat dan komitmen melalui keterlibatan dan komunikasi antar anggota serta menghargai kerjasama, partisipasi dan konsesus(Cameron \& Quinn, 2006, 2011). Dengan adanya kesamaan antara budaya yang saat ini dirasakan dan budaya yang diharapkan artinya pihak menejemen Atlas n Co perlu untuk mempertahankan dan memanfaatkan budaya clan ini untuk kepentingan Atlas $\mathrm{n}$ Co dan untuk mencapai hasil yang maksimal. Dengan budaya clan yang mayoritas sudah dirasakan sekaligus diinginkan oleh karyawan Atlas n Co ini juga yang kemungkinan membuat Atlas $n$ Co mampu bertahan dari segi sumber daya manusianya hingga saat ini, dengan umur kurang lebih 2 tahun dan terus berkembang ditengah gempuran pesaing yang terus berkembang dengan inovasi - inovasi baru dan munculnya coffee shop - coffee shop baru yang juga terus memberikan tawaran - tawaran dan konsep yang baru dan menarik.

Tabel 7. Rekapitulasi Hasil Skor Indikator Budaya Organisasi

\begin{tabular}{|l|l|l|l|}
\hline No & Indikator & Saat Ini & Yang Diharapkan \\
\hline 1 & Karakter Dominan & $32($ Clan $)$ & 30 (Clan) \\
\hline 2. & Kepemimpinan Organisasi & $26($ Clan $)$ & 31 (Clan) \\
\hline 3. & Manajemen Personil & $27($ Clan $)$ & $29($ Clan $)$ \\
\hline 4. & Perekat Organisasi & $33($ Clan $)$ & $35($ Clan $)$ \\
\hline 5. & Strategi yang Ditekankan & $35($ Hierarchy) & $28($ Hierarchy) \\
\hline 6. & Kriteria Keberhasilan & 31 (Hierarchy) & $30($ Clan) \\
\hline
\end{tabular}

\section{PENUTUP}

\section{Kesimpulan}

Saat ini karyawan Atlas $\mathrm{n}$ Co merasakan budaya clan yang sangat kuat sekaligus mengharapkan budaya clan tetap menjadi budaya organisasi di Atlas n Co.

\section{Saran}

Coffee Shop Atlas n Co perlu mempertahankan beberapa aspek atau dimensi dalam budaya organisasi yang ada di Atlas n Co yang sudah sesuai antara yang dirasakan saat ini dan yang diharapkan meliputi karakter dominan, kepemimpinan organisasi, manajemen personil, perekat organisasi dan strategi yang ditekankan termasuk budaya organisasinya sendiri yang juga sudah sesuai antara yang dirasakan saat ini dan yang diharapkan dimasa yang akan datang. Atlas $\mathrm{n}$ Co perlu untuk melakukan penyesuaian pada dimensi kriteria keberhasilan ini, ada 2 opsi , pertama adalah jika manajemen Atlas n Co tetap menginginkan budaya hirarki sebagai kriteria keberhasilan di Atlas n Co, maka Atlas $\mathrm{n}$ Co perlu untuk memberikan pemahaman kepada karyawan agar karyawan mengerti dan memahami apa yang diinginkan oleh perusahaan agar 
Jurnal PRAXIS | Vol. 3 | No. 1 | September 2020

tidak terjadi salah paham serta karyawan juga akan mengetahui alasan dibalik keputusan tersebut. Lalu yang kedua jika Atlas n Co merasa perlu mengikuti kriteria keberhasilan berdasarkan persepsi karyawan dimulai dengan mengembangkan SDM, meningkatkan kerja tim selama operasional dan non operasional, membangun komitmen antar karyawan dan lebih peduli terhadap karyawan terkait pencapaian pencapaian yang sudah diraih.

\section{DAFTAR PUSTAKA}

Bukhori, A., \& Suharnomo, S. (2014). Analisis Pemetaan Budaya Organisasi Menggunakan Organizational Culture Assesment Instrument (OCAI) Pada PT Bandeng Juwana Elrna. Diponegoro Journal Of Management. Diunduh dari : https://ejournal3.undip.ac.id/index. php/djom/article/view/13022

Cameron, K. S., \& Quinn, R. E. (2006, 2011). Diagnosing and Changin Organizational Culture : Based on the Competing Values Framework. San Fransisco: Joh Wiley and Sons, Inc.

Cendana, M. D. (2016). Analisis Pemetaan Budaya Organisasi Menggunakan Organizational Culture Assesment Instrument (OCAI) Pada PT. Angkasa Pura 1 Bandara Ahmad Yani Semarang. E-Journal Undip. Diunduh dari http://eprints.undip.ac.id/49655/

Deal, T. E., \& Kennedy, A. A. (1982). Corporate Culture: The Rites and Rituals of Corporate Life. Massachusetts: Addison0Wesley Publishing Company, Inc.
Frontiera, J. (2009). Leadership and Organizational Culture Transformation in Professional Sport, 109. ABU/INFORM Global (Proquest) database, 109.

Gardner, R. (1999). Benchmarking Organizational Culture : Organizational Culture as a primary factor in safety performance. ABI/INFORM Global (Proquest) database, 44.3 .

Hendry. (2010, Januari 25). Karakteristik Budaya Organisasi. Dipetik Oktober 31, 2019, dari Teorionline:

https://teorionline.wordpress.com/2 010/01/25/karakteristik-budayaorganisasi/

\section{Herlyana, E. (2012). FENOMENA COFFEE SHOP SEBAGAI GEJALA GAYA}

HIDUP BARU KAUM MUDA.

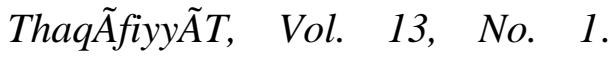
Diunduh Dari : http://ejournal.uinsuka.ac.id/adab/thaqafiyyat/article/ view/43

Huda, F. A. (2016, Maret 26). Pengertian Definisi Operasional. Dipetik November 2, 2019, dari Fatkhan.web.id: http://fatkhan.web.id/pengertiandefinisi-operasional/

Humaniora. (2018, Februari 3). Penikmat Kopi Indonesia Meningkat. Dipetik Oktober 30, 2019, dari Media Indonesia:

https://mediaindonesia.com/read/de tail/143724-penikmat-kopiindonesia- meningkat

Kemendikbud. (2016). KBBI Daring. Dipetik Oktober 2019, dari KBBI Daring: 
Jurnal PRAXIS | Vol. 3 | No. 1 | September 2020

https://kbbi.kemdikbud.go.id/entri/ kafe

Killman, Ralph, H., Saxton, Mary, J., Serpa, \& Roy \& Associate. (1988). Gaining Control of the Corporate Culture. San Fransisco: JosseyBass Publishers.

OCAI online. (2010). Organizational Enterprise Example. Dipetik Oktober 27, 2019, dari OCAI online:

http://www.ocaionline.com/userfile s/file/ocai_enterprise_example_rep ort. pdf

Pratita, H. S. (2016). Pengukuran Budaya Organisasi Sebagai Rujukan Untuk Meningkatkan Daya Saing di Era Global Pada Universitas Sanata Dharma. Universitas Sanata Dharma, 19-23. Diunduh Dari : https://repository.usd.ac.id/6264/2/ 119114112_full.pdf

Suci, D. (2015, Januari Rabu). Setahun Tumbuh 30 Cafe di Kota Semarang, Konsumsi Kopi Meningkat. Dipetik Oktober 26, 2019, dari Tribun Jateng:

https://jateng.tribunnews.com/2015/ 01/14/setahun-tumbuh-30-cafe-dikota-semarang-konsumsi-kopimeningkat

Sugiyono. (2009). Metode Penelitian Kuantitatif Kualitatif dan $R \& D$. Bandung: ALFABETA, CV.

Suryana, C. (2010, Maret 25). Data dan Jenis Data Penelitian. Dipetik november 16, 2019, dari wordpress:

https://csuryana.wordpress.com/2010/03/2 5/data-dan-jenis-data-penelitian/

Sutrisno, E. (2010). Budaya Organisasi. Jakarta: Prenadamedia Group.
Umartias, M., \& Djastuti, I. (2014). Pemetaan Budaya Organisasi Menggunakan Organizational Culture Assesment Instrument (OCAI) Pada PT Kereta Api Indonesia Daerah Operasional 4 Semarang. Diponegoro Journal of Management. Diunduh dari : http://eprints.undip.ac.id/44026/

Wiradinata , M., \& Mustamu, R. H. (2013). ANALISIS BUDAYA ORGANISASI PADA PERUSAHAAN ALAS KAKI. AGORA. Diunduh dari : http://publication.petra.ac.id/index. php/manajemen- bisnis/article/ 